This article is presented in English with abstracts in Spanish and Portuguese

Brazilian Journal of Applied Technology for Agricultural Science, Guarapuava-PR, v.7, n.1, p.63-69, 2014

\section{Cientific Paper}

\section{Abstract}

With the objective of evaluating the effect of low doses of glyphosate in characteristics related to the development of Bidens pilosa, an experiment was set in the experimental area of the Bahia Southwest State University. The installation of the experiment occurred in August of 2012, the plants being cultivated in vases, organized in an entirely randomized design with four repetitions, composed by eight doses of glyphosate herbicide $(0,0.45,0.90,1.35,1.80,2.25,2.70$ and 3.15 g e.a. ha-1). In field, the height, diameter and SPAD

\title{
Development of beggar-ticks (Bidens pilosa) in response to the application of low doses of glyphosate
}

Ricardo de Andrade Silva ${ }^{1}$ Sylvana Naomi Matsumoto ${ }^{2}$ Jerffson Lucas Santos ${ }^{3}$

Luan Santos de Oliveira ${ }^{4}$

Mirlene Nunes de Oliveira ${ }^{4}$ index were evaluated and in the laboratory we assessed the leaf mass, total dry and fresh mass, of root, stalk and leaves of the plants. The obtained data were subjected to general variance analysis and to regression with orthogonal polynomials, aiming the definition of models in order to determine the response curves. The curves showed that for the variables related to mass accumulation there was a reduction as we raised the dose of herbicide, and for variables directly related to the plant etiolating and chlorophyll intensity, the response-dose effect shows to be effective to some low doses.

Keywords: response-dose; hormesis effect; beggar-ticks; low doses.

\section{Desenvolimento de picão preto (Bidens pilosa) em resposta à aplicação de subdoses de glyphosate}

\section{Resumo}

Com o objetivo de avaliar o efeito de subdoses de glyphosate em características relacionadas ao desenvolvimento de Bidens pilosa foi montado um experimento na área experimental da Universidade Estadual do Sudoeste da Bahia. A instalação do experimento ocorreu em agosto de 2012, sendo as plantas cultivadas em vasos, organizadas num delineamento inteiramente casualizado com quatro repetições, composto por oito doses do herbicida glyphosate $(0 ; 0,45 ; 0,90 ; 1,35 ; 1,80 ; 2,25 ; 2,70$ e 3,15 g e.a. ha $\left.{ }^{-1}\right)$. Foram avaliados a campo a altura, o diâmetro, o índice SPAD e no laboratório foram determinadas a área foliar, as massas secas e frescas totais, de raiz, caule e folhas das plantas. Os dados obtidos foram submetidos a analise de variância geral e regressão com polinômios ortogonais visando a definição de modelos para a determinação de curvas de reposta. As curvas mostraram que para as variáveis relacionadas a acúmulo de massa houve diminuição a medida que aumentou-se a dose do herbicida, e para variáveis diretamente relacionadas ao estiolamento das plantas a intensidade de clorofila o efeito dose resposta se mostra efetivo para algumas subdoses.

Palavras-chave: dose-resposta; efeito hormético; picão-preto; subdoses.

\section{Desenvolvimiento de amor seco (Bidens pilosa) en respuesta a las subdosis de aplicación de glifosato}

\section{Resumen}

Con el objetivo de evaluar el efecto de subdosis de gliphosate en las características relacionadas con el desarrollo de Bidens pilosa se montó un experimento en el área experimental de la Universidade Estadual do Sudoeste da Bahia. La

Received at: 06/06/2013

Accepted for publication at: $01 / 03 / 2014$

Professor with Master's at Faculdade Arnaldo Horácio Ferreira. Rua Pará nº. 2280, Mimo I, Luís Eduardo Magalhães - BA, CEP: 47850 000, e-mail: Ricardo_deandrade@yahoo.com.br

2 Agronomy Engineer, Doctor Professor at Universidade Estadual do Sudoeste da Bahia. Estrada do Bem Querer, km 04, Caixa Postal 95, CEP: 45083-900, Vitória da Conquista - Brasil.

3 Agronomy Engineer, Graduate student in Agronomy (Phytotechny) at Universidade Estadual do Sudoeste da Bahia - UESB, CAPES colleger. Vitória da Conquista, BA, Brasil. je.lucas@hotmail.com.

4 Undergraduate student in the agronomy engineering course at Universidade Estadual do Sudoeste da Bahia. Estrada do Bem Querer km 04, Caixa Postal 95, CEP: 45083-900, Vitória da Conquista - Brasil.

Applied Research \& Agrotecnology v7 n1 jan/apr. (2014)

Print-ISSN 1983-6325 (On line) e-ISSN 1984-7548 
Silva et al. (2014)

instalación del experimento se llevó a cabo en agosto de 2012, las plantas fueron cultivadas en contenedores y dispuestas en un diseño completamente al azar con cuatro repeticiones, compuesto de ocho dosis del herbicida gliphosate $(0 ; 0,45$; 0,$90 ; 1,35 ; 1,80 ; 2,25 ; 2,70$ y 3,15 g e.a. ha-1 ${ }^{-1}$. Fueran evaluados a campo la altura, diámetro, índice SPAD y en el laboratorio fueron determinados el área foliar, masa seca y fresca total de raíz, tallo y hojas de las plantas. Los datos fueron sometidos a análisis de varianza general y regresión con polinomios ortogonales con el fin de definir modelos para la determinación de las curvas de respuesta. Las curvas mostraron que las variables relacionadas con la acumulación de masa disminuyeron a medida en que se aumentó la dosis del herbicida, y para las variables directamente relacionadas con el estiolamiento de las plantas a la intensidad de la clorofila el efecto dosis-respuesta se muestra eficaz para algunas subdosis.

Palabras clave: dosis-respuesta; efecto hormético; amor seco; subdosis.

\section{Introduction}

The use of herbicide is a consolidated practice on modern agriculture, its application aims to increase the plant yield and reduce interplant competition between weed and culture (EDGE et al., 2013). On the beginning, the herbicides were used as vegetal regulators, becoming an important technique in the tropical agriculture in order to handle the plant architecture, where its synthetic chemical substances promoted changes in the vegetal metabolism (NAGASHIMA et al., 2010), modifying the physiological and biochemical processes of cultures (CASTRO and VIEIRA, 2001).

Thereby, SILVA et al. (2012b) show that low doses of agrochemicals, originally used as herbicides, stimulate the culture development, from the activation of mechanisms that reduce the effect of adverse conditions. Currently, on the agriculture and on several areas of human health, it has been studied the effect of low doses in living organisms as a way to comprehend the stimulating and beneficial action of toxic substances when ministered in low doses or hormesis.

Active ingredients of herbicides, such as simazine, paraquat, oxifluorfem and glyphosate were studied from the perspective of hormesis effect, where it was found an increase of biomass in treated plants (SILVA et al., 2009). The glyphosate is the most studied for hormesis effects, for it presents physiological action in the plant, inhibiting the enzyme enolpyruvylshikimate phosphate synthase (EPSP), blocking the route of the shikimic acid, indispensable on the synthesis of aromatic amino acids, such as phenylalanine, tyrosine and tryptophan (CEDERGREEN, 2008).

Although the occurrence of hormesis is being investigated in cultivated plants, it's important to direct studies on weed plants, for they possess higher phenotypic plasticity, in relation to cultures. Once elucidated this behavior, the practical application of hormesis in cultivation systalks becomes viable, since they present characteristics that potentiate the competitive capacity, in detriment to the vigor of cultivated plants.

The hormesis effect, as the use of herbicides, is described in the literature, showing its capacity of increasing the biomass of root, stalk and leaves in various plant species, becoming, thus, a technology of agronomic interest in the search for bigger productions through the increase of shikimic acid levels, light capturing, carbon fixation and redistribution of photo assimilates, raising the environmental genotype interaction of cultures and making them more tolerant to abiotic stress (CEDERGREEN and OLSEN, 2009; VASANTHAIAH and KAMBIRANDA, 2011).

Therefore, the phenotypic response of weed plants is of utmost importance for the hormesis application in field, and among these the beggartick (Bidens pilosa), which is a weed plant of higher occurrence and aggressive to agricultural crops, with quadrangular stalk, being able to reach up to one meter high, with short cycle and several annual generations or in a agricultural cycle (MORAES and PUTZKE, 2011), and of fully yellow inflorescence and the fruit when ripe are black, with the pappus in the shape of stiff bristles (HATTORI and NAKAJIMA, 2008).

The beggar-tick has high adaptability to adverse conditions, and capacity of transferring those characteristics to subsequent generations, and due to that there are several biotypes of this plant resistant to increasing doses of herbicides inhibitors of the ALS such as: imazethapyr, nicosulfuron, metsulfuronmethyl e chlorimuron-ethyl, hindering the handling and control of this invader in the most diverse cultures (CHRISTOFFOLETI, 2002). A worrisome fact on the usage of low doses, either tolerance or resistance. 
In view of the exposed, the objective of this study was to assess the effect of low doses of glyphosate in characteristics related to the development of Bidens pilosa.

\section{Material and Methods}

The experiment was conducted in a greenhouse, at the experimental unity of the Bahia Southwest State University - UESB, Vitória da Conquista campus - Bahia, located at $900 \mathrm{~m}$ latitude, at $14^{\circ} 50^{\prime}$ South and longitude $40^{\circ} 50^{\prime}$ West, with average annual temperature of $20.7^{\circ} \mathrm{C}$ and average annual rainfall of $733.9 \mathrm{~mm}$.

We collected seeds of beggar-ticks with tolerance to herbicides inhibitors of ALS in a cotton crop at the west of Bahia, being benefited and selected by size and weight. The sowing was performed in September $18^{\text {th }}$ of 2012 and its emergence occurred after 25 days. The plants were cultivated in vases with five litters capacity, containing soil extracted from the arable layer of the UESB research area, classified as Dystrophic Haplic Cambisol Tb, medium texture.

The design used was entirely randomized, with four repetitions, constituted by eight low doses of glyphosate $(0,0.45,0.90,1.35,1.80,2.25,2.70,3.15 \mathrm{~g}$ e.a. ha-1). Each portion was constituted by four vases, containing 2 plants each, changing their positions weekly for randomizing purposes.

The application occurred in November $10^{\text {th }}$ of 2012, when the plants presented average stalk length of $5 \mathrm{~cm}$ and/or four to five leaves. The application was performed with a pressurized backpack sprayer of $\mathrm{CO}_{2}\left(2 \mathrm{kgf} \mathrm{cm}{ }^{-2}\right)$, attached to a bar containing two nozzles of flat fan 110.02 VS, with solution volume equivalent to $200 \mathrm{~L} \mathrm{ha}^{-1}$; the application was conducted during morning time, with winds of $3 \mathrm{~km}$ $\mathrm{h}^{-1}$ and room temperature of $26^{\circ} \mathrm{C}$.

The analyzed variables occurred 20 days after the application (DAA), where we determined: plant height $(\mathrm{cm})$ : using a graduated ruler, we measured the length from the base until the stalk apex; diameter (mm): with a digital caliper rule, at $5 \mathrm{~cm}$ high, we measured the stalk diameter; the SPAD index: being conducted the reading in the first leaf totally expanded, taking four readings per leaf, using a portable chlorophilometer, model SPAD 502, Minolta, Japan; leaf area $\left(\mathrm{cm}^{2}\right)$ : determined after the collect of all leaves of the evaluated plants, using an area integrator, model LI-3100, LI-COR, USA; fresh mass $\left(\mathrm{g} \mathrm{pl}^{-1}\right)$ : in laboratory we dissected 4 plants per portion, weighed and determined the fresh mass; total dry mass (g plant $\left.{ }^{-1}\right)$ : the vegetal material was dried in a hothouse of circulating air forced to the temperature of $60^{\circ} \mathrm{C}$ for 48 hours, after that period, we weighed it in order to obtain the total dry mass of the leaves, stalks and roots.

The data were subjected to an analysis of bifactorial variance, and the averages were compared by regression analysis, by the method of orthogonal polynomials through the software ASSISTAT 7.6 Beta.

\section{Results and Discussion}

The relations between the leaf area, plant height, stalk diameter and SPAD index with the glyphosate doses are presented in Figures 1A, 1B, $1 C$ and $1 D$, respectively. In resulting validation of variable tendencies related to masses, it was possible to draw a linear model, where the effect of glyphosate application was widely deleterious to the leaf area, the doses being between 0.90 and 3.15 g e.a. ha- ${ }^{-1}$, in a similar behavioral linearity, not varying more than $20 \%$, which was lower than the occurred when using doses of 0.00 and $0.45 \mathrm{~g}$ e.a. ha ${ }^{-1}$, with 200 and $100 \%$, respectively. Thus verifying that the leaf area is one of the most sensitive variables to the application of herbicide (Figure 1A), such behavior was described by FARIAS et al. (2012), who justify this effect due to the decrease of the EPSP activities, responsible for the mass augmentation and physiological effect of the plant growth.

In Figure 2B, it is verified that the found results regarding plant height present opposite behavior to the literature that depicts hormesis, with a quadratic curve, the lowest height being correspondent to 0.45 to $2.70 \mathrm{~g}$ e.a. $\mathrm{ha}^{-1}$, where they are intermediaries and equidistant. In the same figure we find that in the dose of $3.15 \mathrm{~g}$ e.a. ha- ${ }^{-1}$ there was significant effect on the height increase, higher than 10\%. For YAMADA and CASTRO (2004), the glyphosate acts over the tryptophan synthesis, substance described by SALISBURY and ROSS (2012) as precursor on the auxin hormone formation, explaining, thereby, the possible relation between the stalk mass and height, showing that the height presented on the dose of $3.15 \mathrm{~g}$ e.a. ha- ${ }^{-1}$ is not related to mass, but yet to a shading, resulting of the increase on auxin synthesis, validating the response-dose effect described by VELINI et al. (2008).

For the SPAD index (Figure 1C) we find that 
in the adjusted cubical model there is a variation of dose in relation to the other analyzed variables, that is, the intensity of the green coloration is widely affected by the effect due to greater penetration of herbicide in the plant cuticle. Since the low doses are more vulnerable to bad weather than lethal doses, therefore, each low dose can suffer greater or lesser effect of climate aspects. Thus, it is possible to observe the positive effect of the application in low doses of 0.45 and 2.25 g e.a. ha- ${ }^{-1}$, with increment of $14 \%$ and $6 \%$, respectively, in the SPAD index. Data that show the effect of low doses in other species were not found, but PEREIRA et al. (2011) report higher phytotoxicity on varjão and eucalyptus, respectively, in response to the increase of glyphosate doses, consequently, it is likely to decrease the intensity of the color green, since the herbicide phytotoxicity is characterized by the yellowing of leaves.

The observed tendency for the stalk diameter corroborates with most of the existent literature, adjusting in a quadratic model, whereas the doses of $0.45,1.35,1.80$ and 2.25 g e.a. ha ${ }^{-1}$ present diameter increase in the order of $6 \%$ to $26 \%$, and in the dose of 2.7 g e.a. ha $^{-1}$, a stalk diameter decrease (Figure 1D).
Similar results were described by MESCHEDE et al. (2008), although with no theoretical description of this behavior.

In Figure 2, it is presented the relations between the dry and fresh masses of the culture and the glyphosate doses. The stalk fresh mass (SFM) and stalk dry mass (SDM) were affected by the application of herbicide where it is observed that the dry mass of the stalk suffered sharp decrease, that is, as the dose was raised, the mass diminished, evidencing the deleterious effect of the substance in the tissue, thus, it is possible to trace a linear model (Figure 2A). Still in Figure 2, it is possible to verify that for the stalk dry mass, even tracing a linear model, the difference between the treatments was inferior to the observed for the mass, illustrating that the lower the herbicide dose, the greater the water content in the tissues, showing, thus, the deleterious effect of the used low doses. The mass decrease is related to the interruption of the mitosis process and rupture of the plastids, restraining its augmentation (CUNHA, 2004). Similar effect was observed by MELHORANÇA FILHO et al. (2011) for conventional soy.

Figure 2B shows the root fresh mass (RFM)
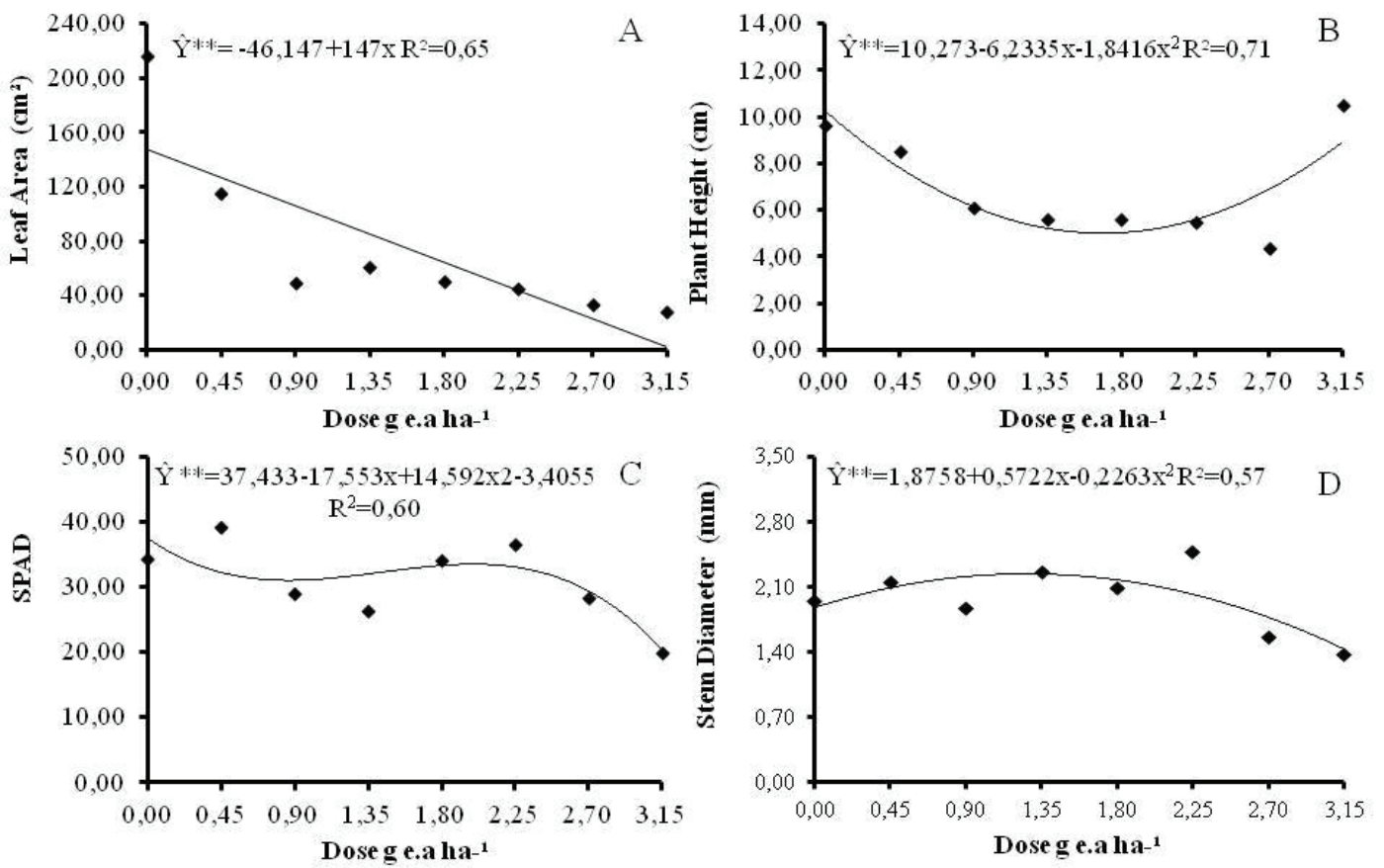

Figure 1. 1A, Leaf area $\left(\mathrm{cm}^{2}\right), 1 \mathrm{~B}$, Plant height $(\mathrm{cm}), 1 \mathrm{C}$, SPAD index and 1D, Stalk diameter $(\mathrm{mm})$ at 20 days after the application of glyphosate. 

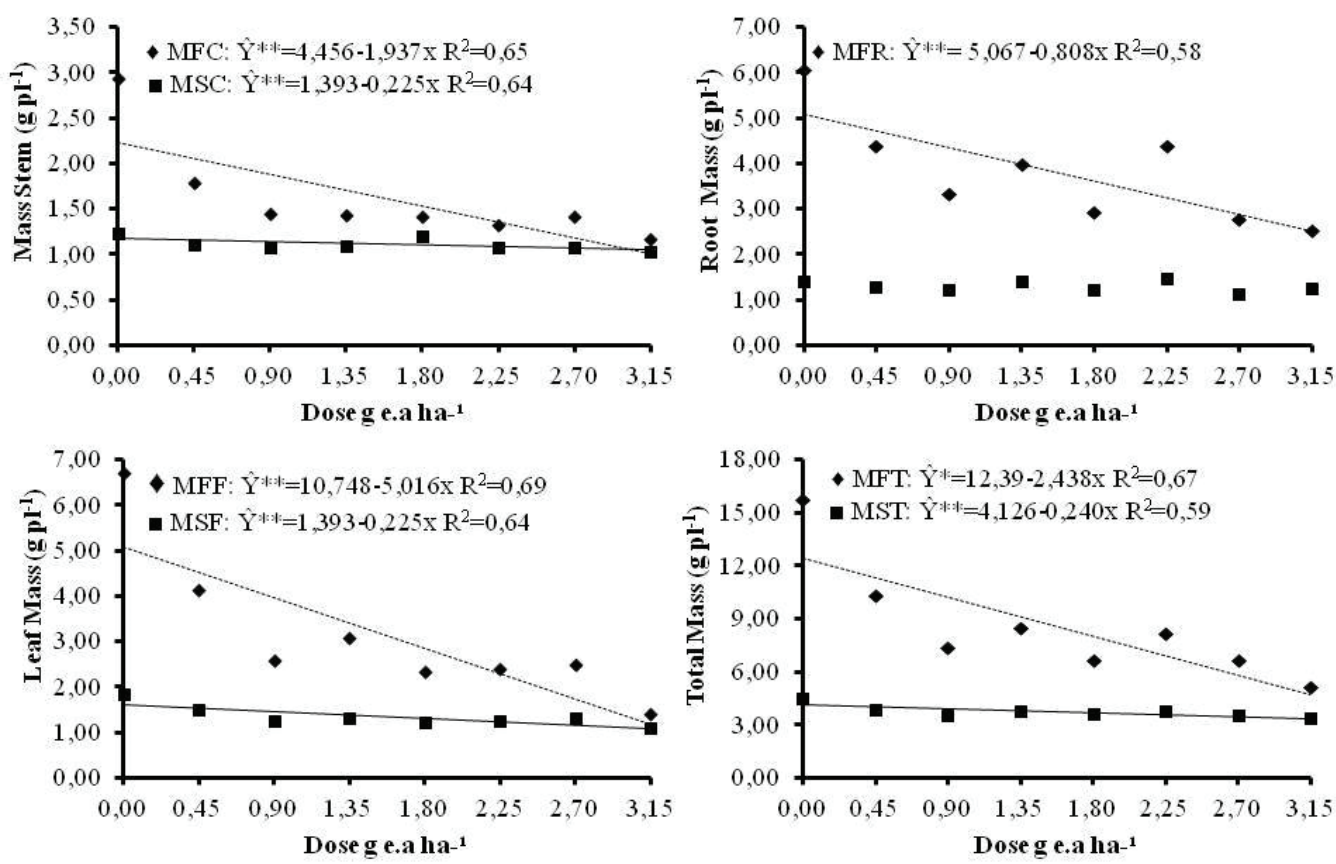

Figure 2. Stalk fresh $(\bullet)$ and dry $(\bullet)$ mass (2A), root (2B), leaf (2C) and total (2D) in grams, at 20 days after the application of glyphosate.

and root dry mass (RDM), where it is verified that for the MFR there's a linear tendency of reduction, except on doses of 1.35 and 2.25 g e.a. ha- ${ }^{-1}$, on which there's an alteration on tendency, demonstrating the biological aspect of hormesis, where each species and individual acts differently when subjected to different applied doses. For the MSR there was no significant difference between treatments, thus it is observed that the dry mass accumulation is not influenced like the fresh mass. MIRANDA et al. (2004) quotes that this deleterious behavior of the low doses was described by several researchers, where it was found the reduction of both aerial and underground parts of the plant, mainly due to the decrease of secondary root emission. Such results are in accordance with MELHORANÇA FILHO et al. (2011), showing that the root mass tends to follow the patterns presented by the aerial part masses.

The leaf fresh (LFM) and dry (LDM) mass presented similar behavior of the stalk mass, being traced linear models, respectively (Figure 2C). The LFM decreased as the doses were increased, verifying a behavioral variation between the points as we increased the dose of the glyphosate herbicide. The LDM varied in a simple way (Figure 2C), expressing and ratifying the results of the previous variables, showing that the herbicide acts markedly on the accumulation of water in the plant.

VELINI et al. (2008), after evaluating several vegetal species under the effect of low doses of glyphosate, showed that the doses capable of promoting the hormesis effect in Commelina benghalensis are between 0.1 and 1.0 g e.a. $\mathrm{h}^{-1}$, verifying that, for the beggar-tick, the dose must be low and that the phonological stage at the moment of the application influences the final result.

The sum of the previous masses generated the total fresh mass (TFM) and total dry mass (TDM) (Figure 1D), where it's verified a similarity of the studied tendencies, tracing linear models for the TFM and TDM. The observed results validate the theory presented by KRUSE et al. (2000), which predicts that the inhibition of EPSP by the glyphosate would cause a decrease of carbon accumulation, since the herbicide interferes in the shikimate pathway, responsible for the fixation of 20 to $35 \%$ of vegetal mass, which explains the linear tendency of decrease of mass augmentation.

One of the main limitations of glyphosateusage for hormesis effect in field is the instability of the 
results, which for MELHORANÇA FILHO et al. (2011) may be related to the high dependency of the necessary doses in order to facilitate the penetration of substances in the leaf cuticle. GALLI and MONTEZUMA (2005) demonstrate that, besides the doses, climatic factors, such as temperature and wind, may turn the application of doses inefficient.

\section{Conclusions}

According to the obtained results, it is possible to verify that in general there is no beneficial effect on the application of low doses of glyphosate over the accumulation of leaf mass and area, stimulation in specific points the SPAD index, height and diameter of the beggar-tick.

\section{References}

CASTRO, P. R. C.; VIEIRA, E. L. Aplicações de reguladores vegetais na agricultura tropical. Guaíba: Livraria e EditoraAgropecuária, 2001. 132 p.

CEDERGREEN, N. Herbicides can stimulate plant growth. Weed Res. 48, 429-438, 2008.

CEDERGREEN, N.; OLESEN, C. F. Can glyphosate stimulate photosinthesis? Pesticide Biochemistry and Physiology. v.96, p.140-148, 2009.

CHRISTOFFOLETI, P. J. Curvas de dose-resposta de biótipos resistente e suscetível de Bidens pilosa L. aos herbicidas inibidores da ALS. Scientia Agricola, v.59, n.3, p.513-519, jul./ set. 2002.

CUNHA, C. S. M. Comparação de métodos na detecção de sementes de soja geneticamente modificada, tolerante ao glifosato. 2004. 24f. Dissertação (Mestrado em Ciência e Tecnologia de Sementes) - Faculdadede Agronomia “Eliseu Maciel”, Universidade Federal de Pelotas, Pelotas, 2004.

EDGE, C. B.; GAHL, M. K.; THOMPSON, D. G.; HOULAHAN, J. E. Laboratory and field exposure of two species of juvenile amphibians to a glyphosate-based herbicide and Batrachochytriumdendrobatidis. Science of the Total Evironment. Vol. 444, p. 145-152, 2013.

FARIAS, C. C. M.; RODON NETO, R. M.; YAMASHITA, O. M.; FARIAS, C. B. M. Efeitos de subdoses de glyphosate em plantas jovens de seringueira (Hevea brasiliensis Aubl.). Revista Brasileira de Herbicidas, v. 11, n. 1, p. 119-125, jan/abr, 2012.

GALLI, A. J. B.; MONTEZUMA, M. C. Alguns aspectos da utilização do herbicida glyphosate na agricultura.2005. Artigo em Hypertexto. Disponível em <http://www.monsanto.com.br/roundup/ glyphosate/capitulo3/capitulo3_2.asp>. Accessed in 20/03/2013.

HATTORI, E. K. O.; NAKAJIMA, J. N. A família Asteraceae na Estação de Pesquisa e Desenvolvimento Ambiental Galheiro, Perdizes, Minas Gerais, Brasil. Rodriguésia 59 (4): 687-749, 2008.

KRUSE, N. D.; MICHELANGELO, M. T.; VIDAL, R. A. Herbicidas inibidores da EPSPs: revisão de literatura. Revista Brasileira de Herbicida, v. 1, n. 2, p. 139-146, 2000.

MELHORANÇA FILHO, A. L.; MARTINS, D.; PEREIRA, M. R. R.; ESPINOSA, W. R. Efeito de glyphosate sobre característica produtiva em cultivares de soja transgênica e convencional. Biosc. Journal., v. 27, n. 5, p. 686-691, sept/oct, 2011.

MESCHEDE, D. K.; VELINI, E. D.; CARBONARI, C. A. Baixas doses de glyphosate e seus efeitos no crescimento de Commelina benghalensis. Revista Brasileira de Herbicidas. V. 7, n. 2, p. 53-58, jul/dez, 2008.

MIRANDA, D. M.; TILLMANN, M. A. A.; BALERINI, F.; VILLELA, F. A. Bioensaios na detecção equantificação de sementes de soja geneticamente modificada em amostras convencionais de sementes. In: SEMINÁRIO PANAMERICANO DE SEMILLAS, 19., 2004, Asunción. Anais... Asunción: FELAS, 2004. p. 342.

MORAES, L. B.; PUTZKE, M. T. L. Estudo histológico da parte aérea de Bidens pilosa L. Anais do III Simpósio de Biodiversidade. Santa Maria-RS, 2011.

NAGASHIMA, G. T.; MIGLIONANZA, E.; MARUR, C. J.; YAMAOKA, R. S.; BARROS, A. S. R.;MARCHIOTTO, 
Development of beggar-tiks... Desenvolvimento de picão-preto...

F. Qualidade fisiológica de sementes de algodão embebidas em solução de cloreto de mepiquat. Ciênc. Agrotec. Lavras, v.34, n.3, p. 681-687, 2010.

PEREIRA, M. R. R.; RODRIGUES, A. C. P; CAIO, F. C.; MELHORANÇA FILHO, A. L.; MARTINS, D. Absorção de Subdoses Glyphosate aplicadas em diferentes locais de plantas de eucalipto. Revista Árvore, v. 35, n. 3, 2011, pp. 589-594.

SILVA, J. C.; ARF, O.; GERLACH, G.A.X.; KURYIAMA, C. S.; RODRIGUES, R. A. F. Efeito hormese de glyphosate em feijoeiro. Pesq. Agropec. Trop., Goiânia, v. 42, n. 3, p. 295-302, 2012a.

SILVA, M. A.; ARAGÃO, N. C.; BARBOSA, M. A.; JERONIMO, E. M.; CARLIN, S. D. Efeito hormótico de gliphosate no desenvolvimento inicial de cana-de-açúcar. Bragantia, Campinas, v.68, n.4, p.973-978, 2009.

SILVA, R. A.; MATSUMOTO, S. N.; BARBOSA, G. M.; COSTA, R. Q.; OLIVEIRA, M. N. Aplicação de subdoses de glyphosate na fase de estabelecimento da cultura da soja e do milho. ENCICLOPÉDIA BIOSFERA, Centro Científico Conhecer, Goiânia, v.8, n.15; p. 140-149, 2012.

VASANTAHIAH, H. NK.; KAMBIRANDA, D. Plants and Environment. Printed in Croatia, p. 284, 2011.

VELINI, E. D.; ALVES, E.; GODOY, M. C.; MESCHEDE, D. K.; SOUZA, R. T.; DUKE, S. O. Glyphosate applied at low doses can stimulate plant growth. Pest Manag Sci, 64:489-496, 2008.

YAMADA, T.; CASTRO, P. R. C. Efeitos do glyphosate nas plantas: implicações fisiológicas e agronômicas. International Plant Nutrition Institute-IPNI, Encartetécnico, setembro, 2007. 